\title{
WEBSITE PEMESANAN PENGINAPAN DI PALANGKA
}

\section{RAYA}

\author{
Adi Novari Chandra ${ }^{a, 1, *}$, Felicia Sylviana ${ }^{b, 2}$, Nahumi Nugrahaningsih ${ }^{\mathrm{c}, 3}$ \\ ${ }^{\text {a }}$ Universitas Palangka Raya, J1. H. Timang \\ ${ }^{\mathrm{b}}$ Universitas Palangka Raya, Jl. H. Timang \\ ${ }^{\text {c }}$ Universitas Palangka Raya, Jl. H. Timang \\ ${ }^{1}$ adinovari@gmail.com*, ${ }^{2}$ felicia.upr@gmail.com, ${ }^{3}$ nahumi@gmail.com \\ * corresponding author
}

AR T IC L E INF O

Keywords

Website

Booking

Accommodation

Waterfall

\section{ABST R ACT}

Internet as a means of fast and easy information media for the general public, in this case can also be used to find accommodation in Palangka Raya, Website booking accommodation in Palangka Raya also to facilitate customers in the process of booking a stay where customers can know the availability of room, room facilities and last room price also make it easier for the property to use it as a media information on the The property can manage the accommodation, rooms, room facilities as well as confirmation of orders from customers, then admin tasks as the manager of the website.

The method of software development used is the advanced waterfall methodology, namely analysis, design, coding and testing. At the analysis stage, there was an analysis of old systems and new systems and analysis of databases using the DFD methodology after that design. In testing stage using Black Box testing method, which is a testing strategy that focuses solely on the functionality factor and software specifications. Suggestion for development of this website by adding filtering feature with map concept based on route or nearby location.

\section{Pendahuluan}

Pemanfaatan teknologi informasi dan internet dapat digunakan sebagai sarana memperoleh informasi-informasi mengenai website. Internet merupakan sarana yang cepat dan mudah dalam menyebarkan informasi dan mencari informasi yang dibutuhkan dengan mengunjungi situs atau website.

Adapun cara lama untuk menyampaikan informasi yang masih kebanyakan menggunakan media cetak dan lainnya sangat terbatas sehingga informasi yang diperoleh kurang akurat dan biaya yang dikeluarkan lebih mahal di bandingkan melalui website, dalam kasus ini termasuk adalah proses pemesanan penginapan yang kebanyakan masih dilakukan secara manual baik datang langsung ke penginapan atau pemesanan dengan kertas formulir atau pembukuan yang terkadang dapat menyebabkan terjadinya kesalahan data. Oleh karena itu Website dianggap efektif untuk melakukan publikasi dan pemasaran informasi baik organisasi, lembaga, instansi pemerintahan atau yang bersifat informasi untuk umum yang juga pemesanan penginapan ini termasuk diantaranya.

Menimbang pengguna internet pada saat ini berkembang sangat pesat dan kebutuhan informasi yang cepat dan untuk kemudahan mengakses informasi untuk pemesanan penginapan dan membantu juga proses pihak penginapan dengan menggunakan sistem informasi yang berbasis website dengan menggunakan bahasa pemrograman PHP, basis data MySQL, dan menggunakan metode pengembangan perangkat lunak Waterfall, maka User dapat mengakses informasi dan proses 
pendataan pemesanan penginapan dapat mempermudah dan mempercepat proses pemesanan serta dapat diakses kapanpun dan dimanapun tanpa mengenal jarak dan waktu, serta yang diharapkan dapat menampilkan informasi ataupun menampilkan fitur yang terkait yang dibutuhkan oleh User.

\section{Pengertian Penginapan atau Akomodasi}

Akomodasi atau yang biasa kita sebut dengan "Penginapan" adalah sebuah tempat yang dijadikan atau difungsikan sebagai tempat tinggal sementara bagi orang yang sedang berada dalam perjalanan, dimana orang tersebut diharuskan untuk berada atau tinggal jauh dari rumah lebih dari 1 hari. Penginapan haruslah menyediakan keperluan dan mememenuhi standar minimal seperti tempat tidur, tempat istirahat, faktor keselamatan, berlindung dari suhu dingin atau hujan dan panas, fasilitas penyimpanan barang, hingga akses ke kebutuhan umum rumah tangga. Pada hakikatnya, ada banyak sekali jenis penginapan [6]

Berikut ini adalah berbagai jenis penginapan beserta kriterianya masing-masing :

\section{Guest House atau Wisma Tamu}

Pada dasarnya guest house merupakan versi mini dari hotel. Fasilitas yang ditawarkan oleh guest house biasanya lebih sederhana dari hotel.

2. Mess

Jenis penginapan tanpa fasilitas makan yang difungsikan sebagai tempat tinggal bagi karyawan, pegawai, dan anggota lain dalam suatu instansi untuk kelompok tertentu (single atau trainee).

3. Home stay

Adalah jenis penginapan yang mulanya berasal dari rumah penduduk yang kemudian ditingkatkan sarana dan prasarananya hingga memenuhi standar kebersihan, kelayakan, dan kesehatan.

4. Hostel atau Asrama

Penginapan milik suatu badan nonkomersil yang umumnya digunakan untuk kaum muda, dimana pria dan wanita diletakkan pada area yang terpisah. Asrama biasanya disewakan dengan harga sangat murah dan juga menyediakan fasilitas.

\section{Website}

Website atau situs dapat diartikan sebagai kumpulan halaman yang menampilkan informasi data teks, data gambar diam atau gerak, data animasi, suara, video dan atau gabungan dari semuanya, baik yang bersifat statis maupun dinamis yang membentuk satu rangkaian bangunan yang saling terkait dimana masing-masing dihubungkan dengan jaringan-jaringan halaman (hyperlink) [1].

Secara garis besar, website bisa digolongkan menjadi 3 bagian yaitu:

a. Website Statis

Website statis adalah web yang mempunyai halaman tidak berubah. Artinya adalah untuk melakukan perubahan pada suatu halaman dilakukan secara manual dengan mengedit code yang menjadi struktur dari website tersebut.

b. Website Dinamis

Website dinamis merupakan website yang secara struktur diperuntukkan untuk update sesering mungkin. Biasanya selain utama yang bisa diakses oleh user pada umumnya, juga disediakan halaman backend untuk mengedit konten dari website. Biasanya sebuah website dinamis terhubung ke database sehingga dapat dengan mudah menyimpan dan menarik informasi dengan cara yang terorganisir dan terstruktur. Contoh umum mengenai website dinamis adalah web berita atau web portal yang didalamnya terdapat kebudayaan berita, polling dan sebagainya.

c. Website Interaktif

Website Interaktif adalah web yang saat ini memang sedang populer. Salah satu contoh website interaktif adalah blog dan forum. Di website ini user bisa berinteraksi dan beradu argumen mengenai apa yang menjadi pemikiran mereka. Biasanya website seperti memiliki moderator untuk mengatur supaya topik yang diperbincangkan tidak keluar jalur. 


\section{Metodologi Penelitian}

Metodologi penelitian yang digunakan dalam merancang dan membangun Aplikasi ini meliputi metode pengumpulan data yaitu dengan menanyakan informasi tentang kos dan datadata yang bersangkutan langsung kepada sumbernya. Menggunakan metode pengembangan perangkat lunak waterfall [1] yang meliputi :

1. Requirements Definition (Definisi Kebutuhan)

2. System and Software Design (Desain Sistem dan Perangkat Lunak)

3. Implementation and Unit Testing (Implementasi dan Pengujian Unit)

4. Integration and System Testing (Pengintregrasian dan Pengujian Sistem)

5. Operation and Maintenance (Pengopera sian dan Pemeliharaan)

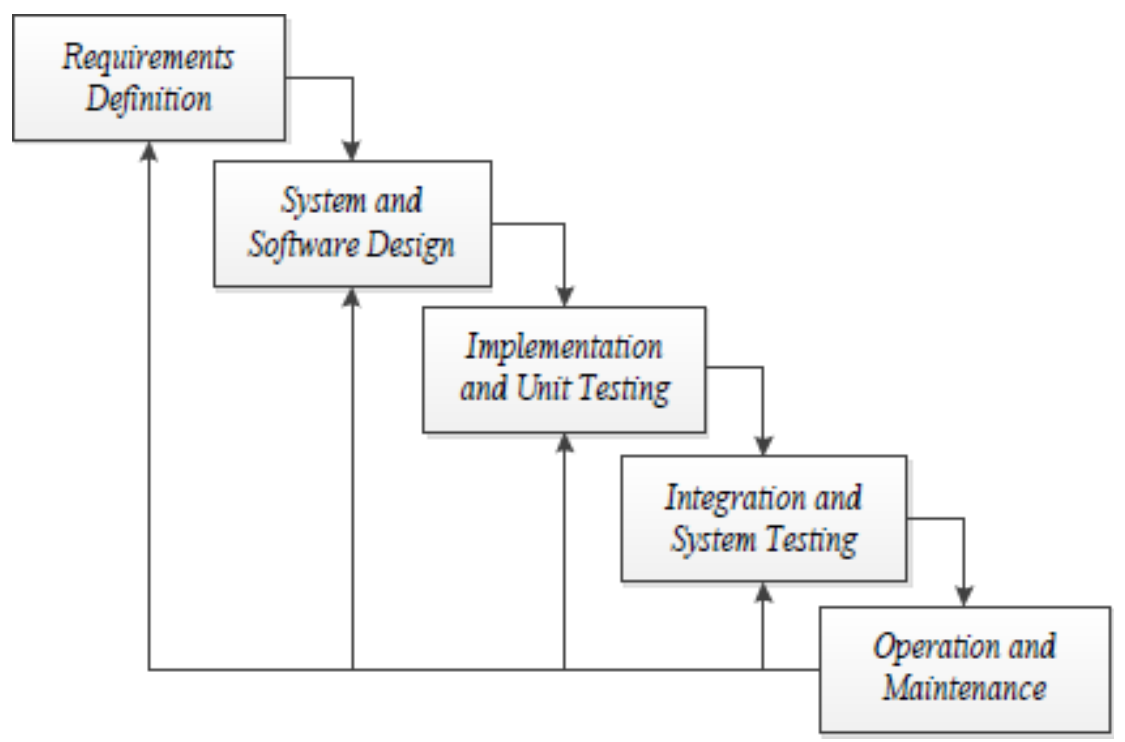

Gambar 1. Metode Waterfall

\section{Hasil dan Pembahasan}

5.1 Flowchart Sistem Lama 


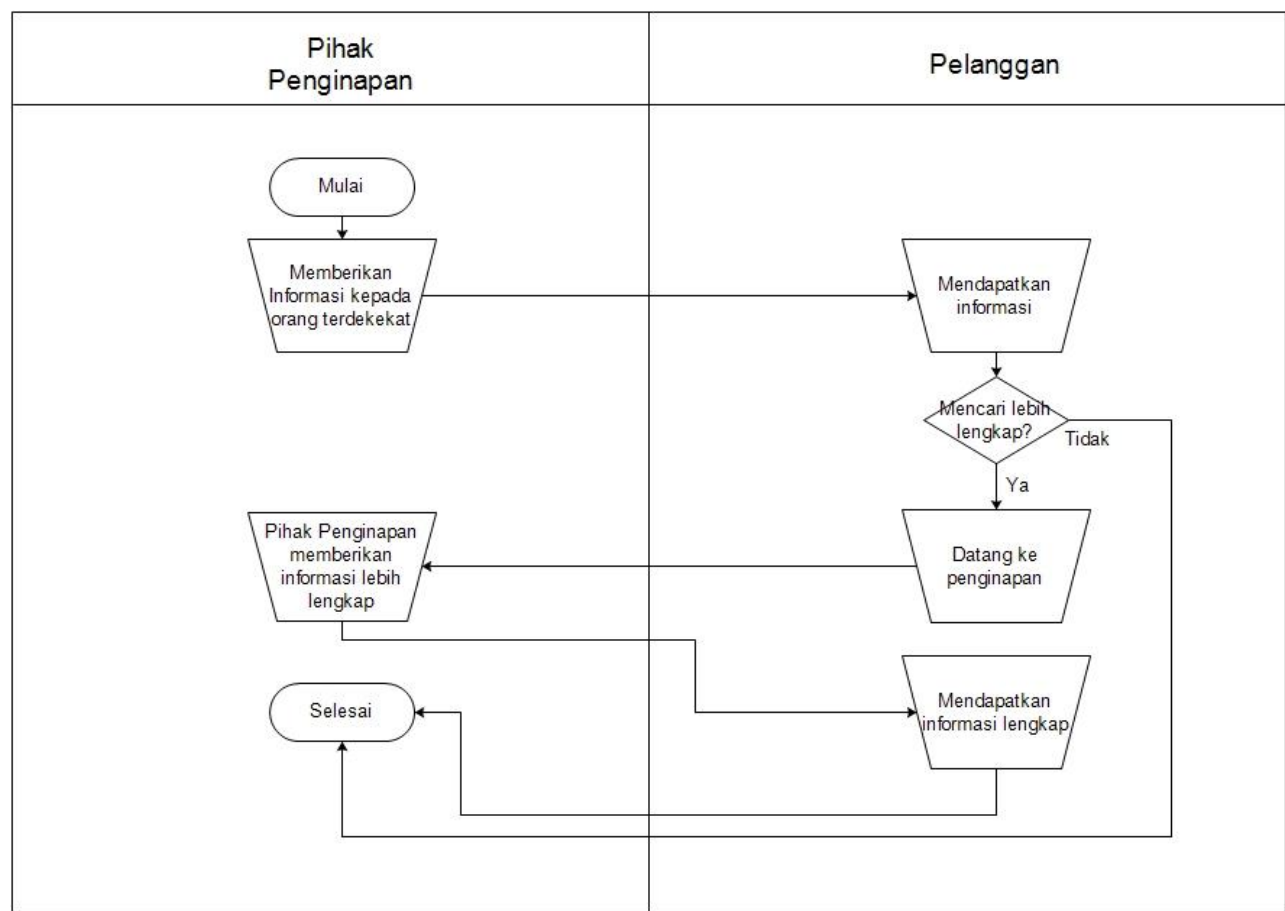

Gambar 2. Flowchart Sistem Lama

\subsection{Flowchart Sistem Baru}

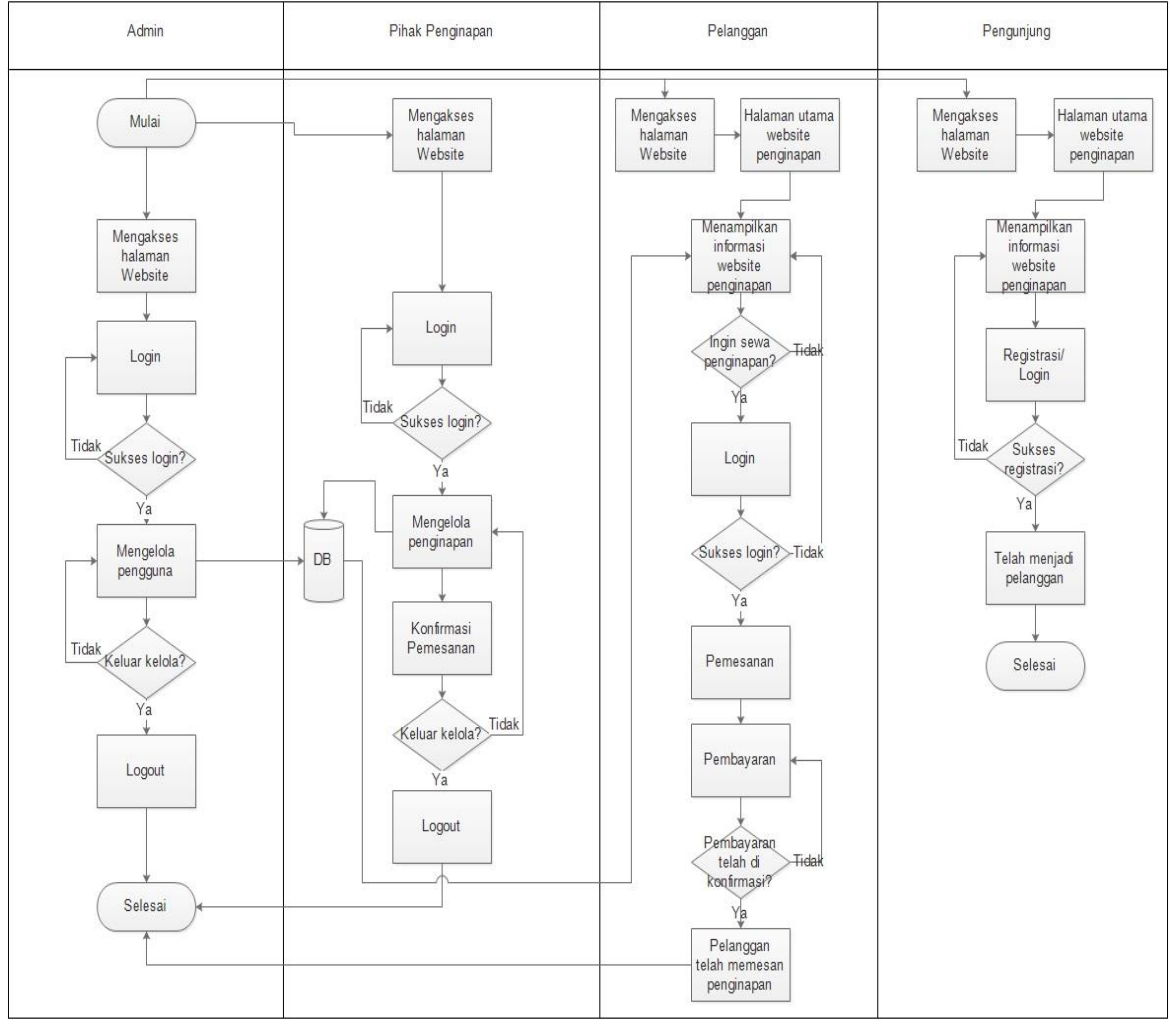

Gambar 3. Flowchart Sistem Baru 


\subsection{Diagram Konteks}

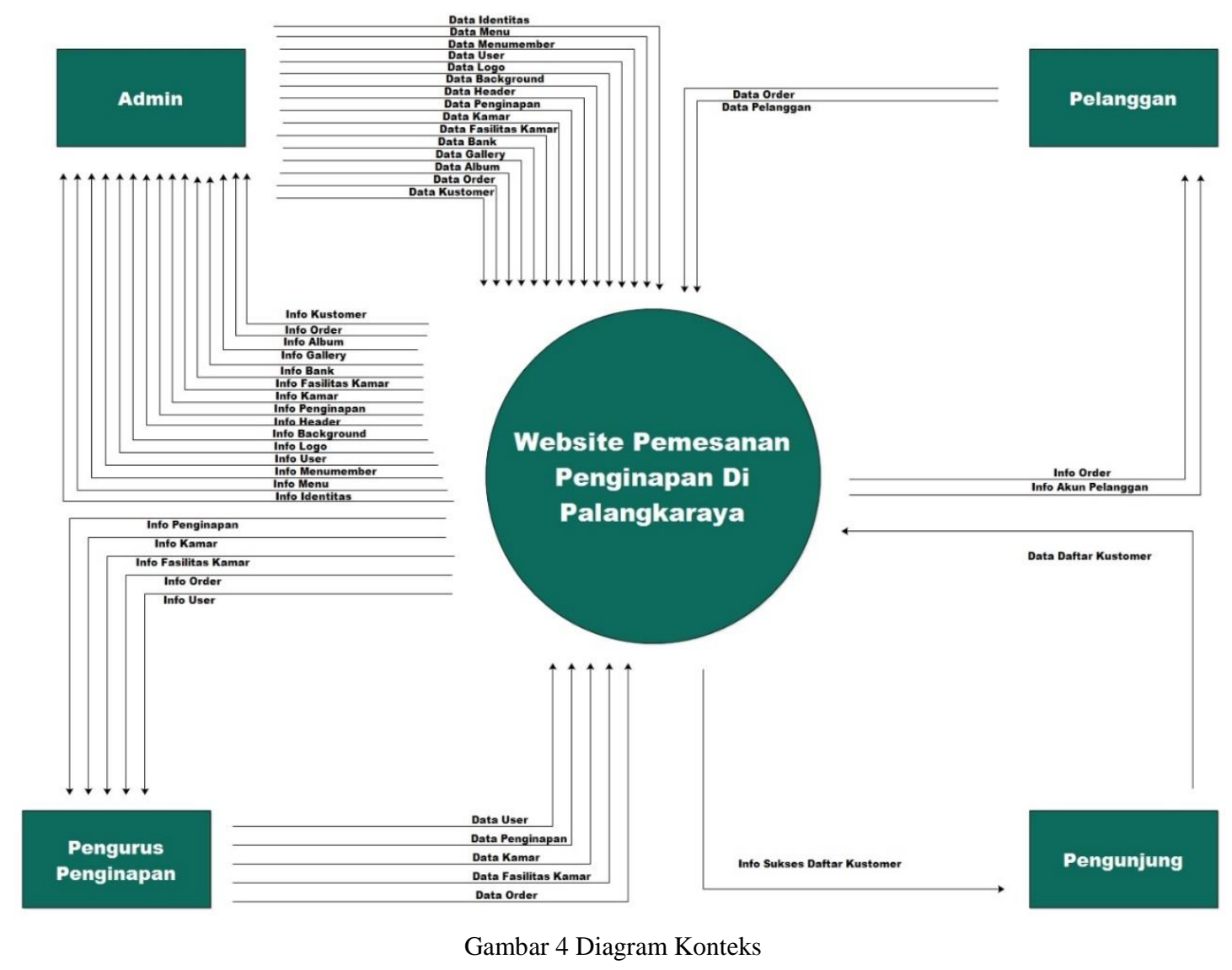

5.4 Diagram Level 0

Dimana DFD [5] Level 0 ini menggambarkan proses-proses dan aliran data di dalam sistem. Pada DFD Level 0 ini terlihat proses-proses yang dilakukan pada sistem serta penyimpanan database yang digunakan.Dapat dilihat pada gambar 5: 


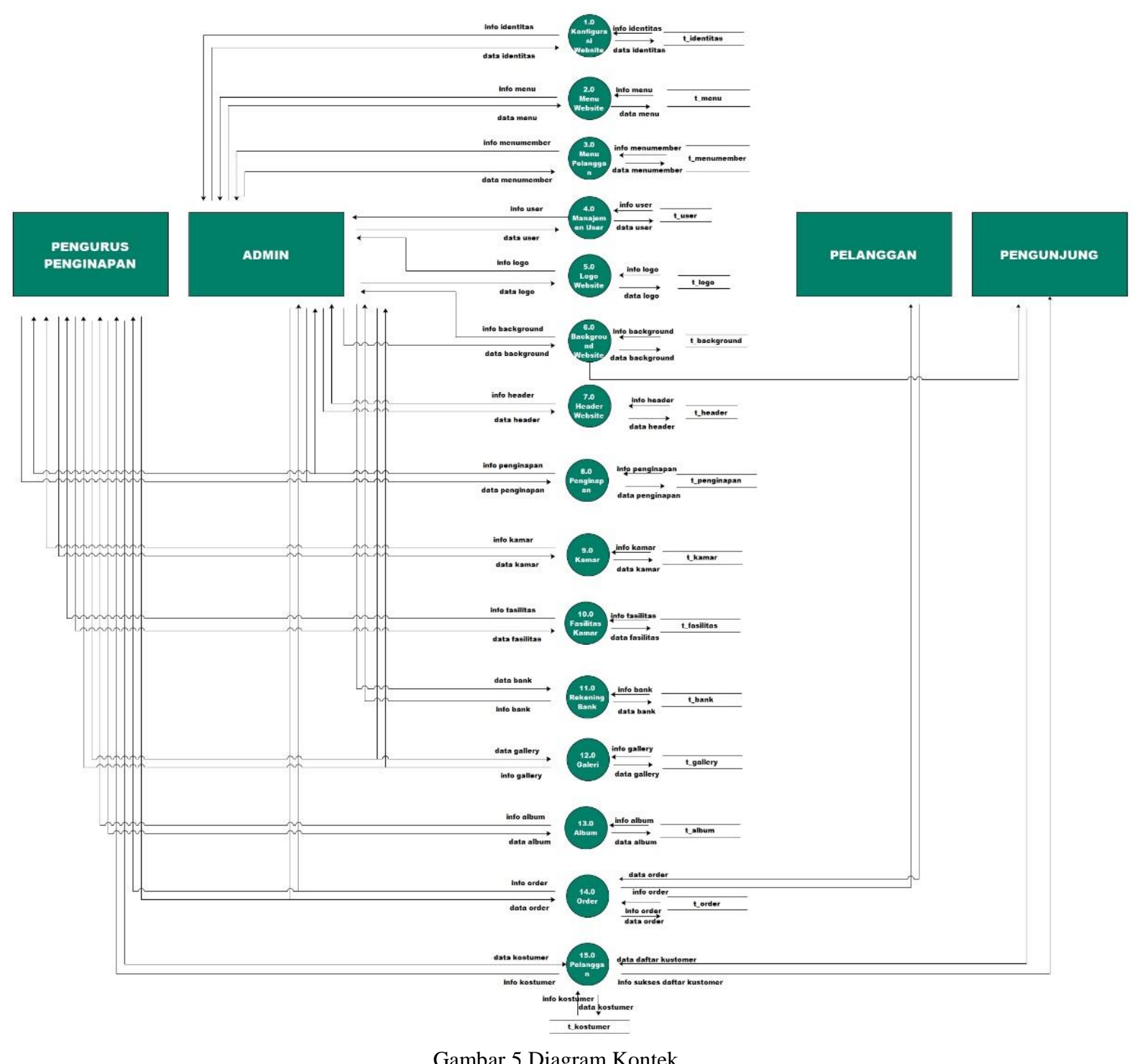

5.5 ERD

Entity Relational Diagram (ERD) [1] yang adalah diagram yang memperlihatkan entitas-entitas yang terlibat dalam suatu sistem serta hubungan-hubungan (relasi) antar entitas tersebut. Berikut gambar ERD dari sistem ini, terlihat pada gambar 6: 


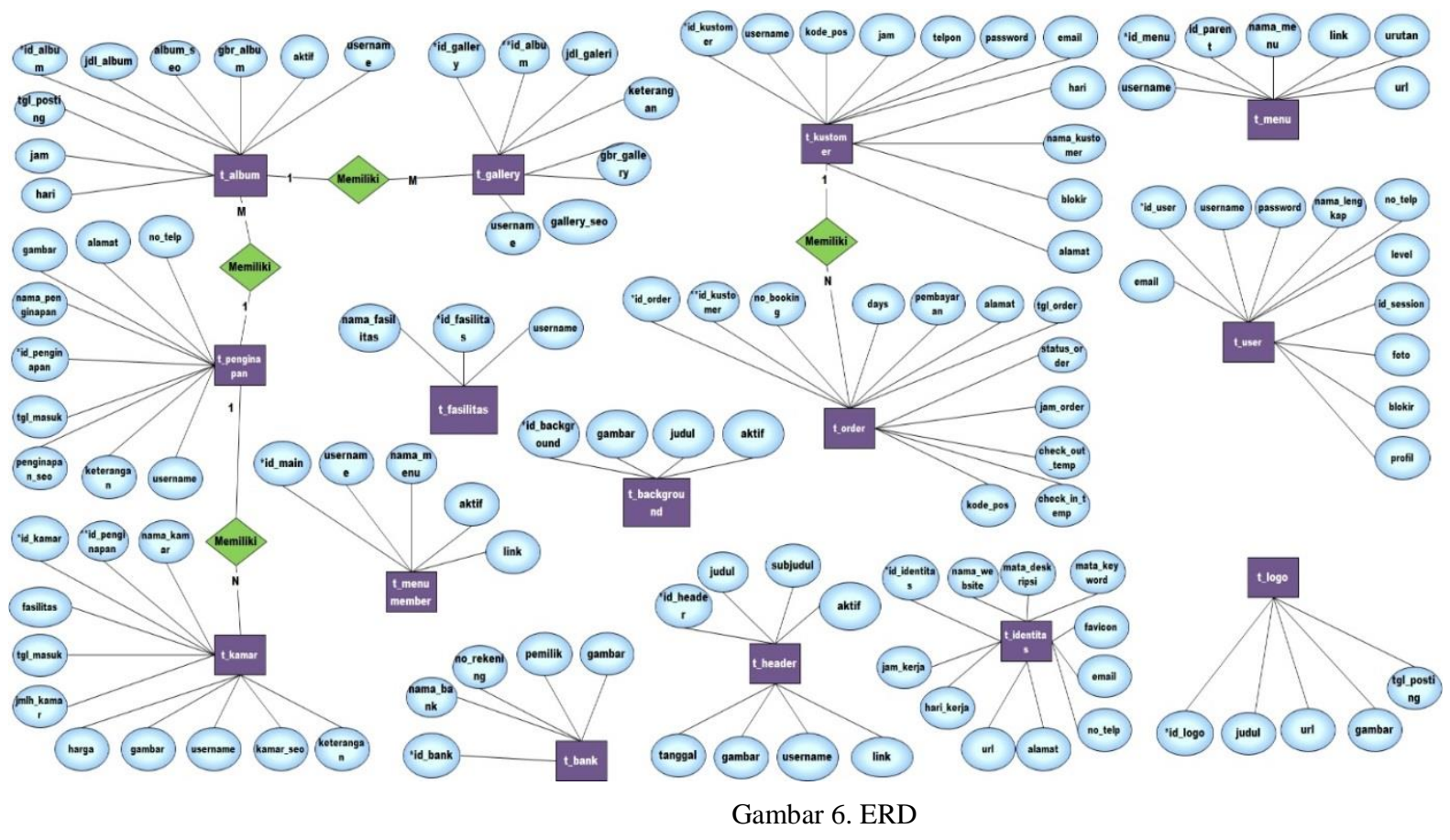

5.6 Antarmuka Pada Website

1. Halaman Kelola Penginapan

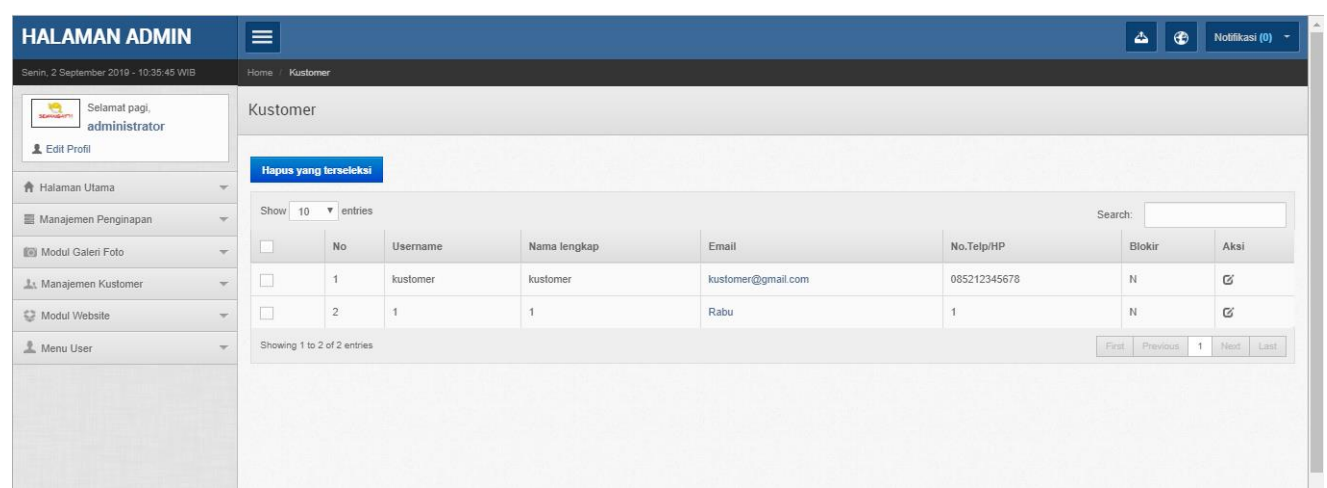

Gambar 7. Halaman Kelola Penginapan

2. Halaman Kelola Kamar

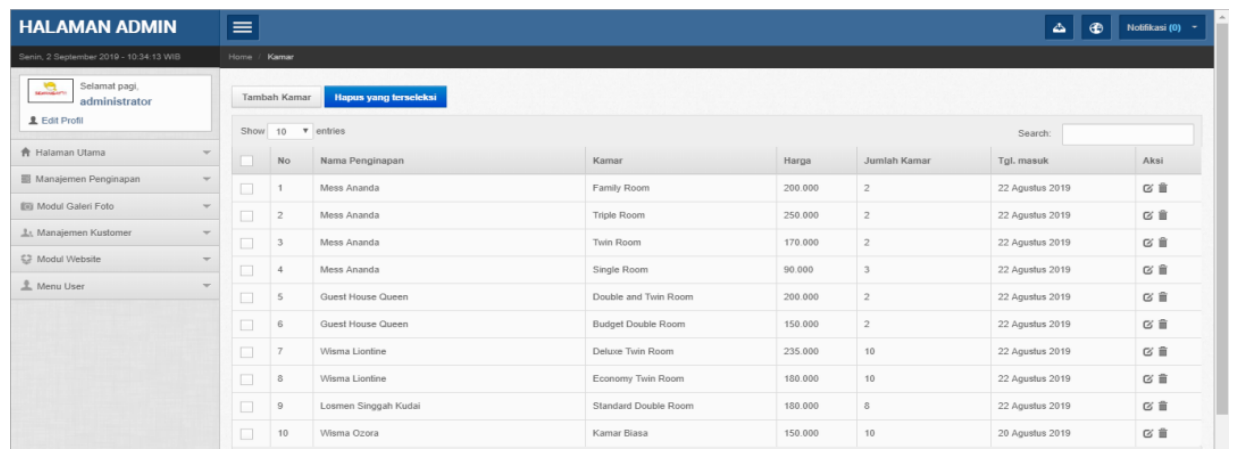

Gambar 8. Halaman Kelola Kamar 


\section{JURNAL TEKNOLOGI INFORMASI}

Jurnal Keilmutan dan Apilkasi Bidang Teknik Informatilka

[E-ISSN 2656-0321]

[Vol 15 No 1]

[ Januari 2021]

3. Halaman Order Masuk

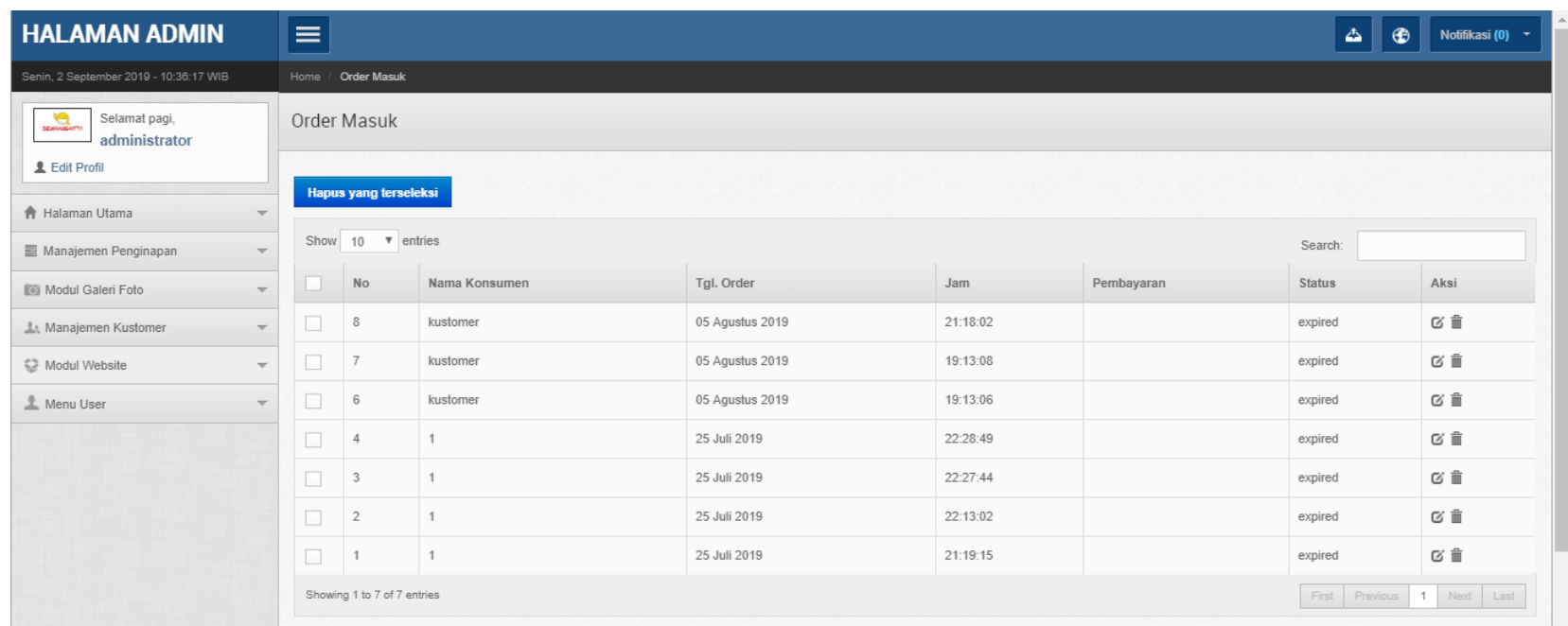

Gambar 9. Halaman Order Masuk

4. Halaman Manajemen User

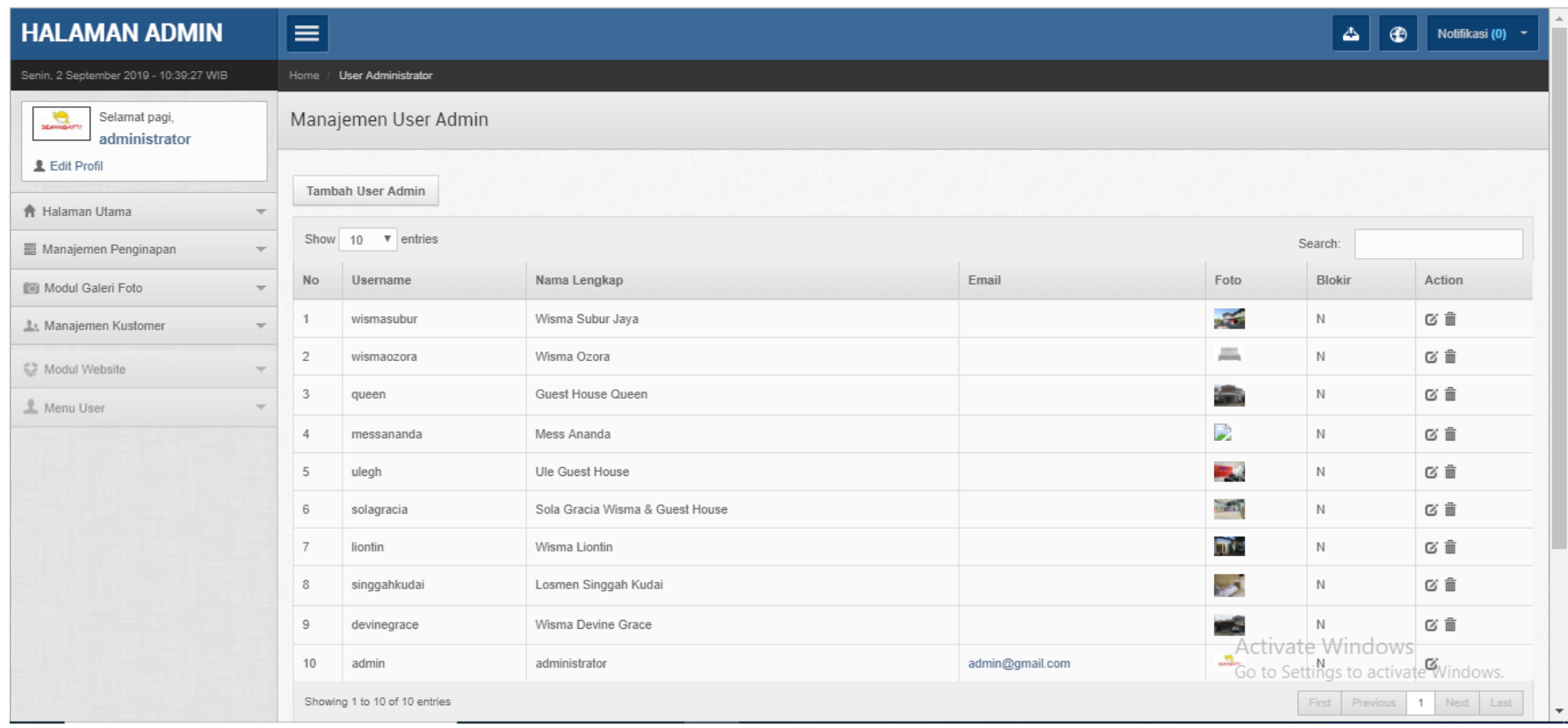

Gambar 10. Halaman Manajemen User 
5. Halaman Manajemen User

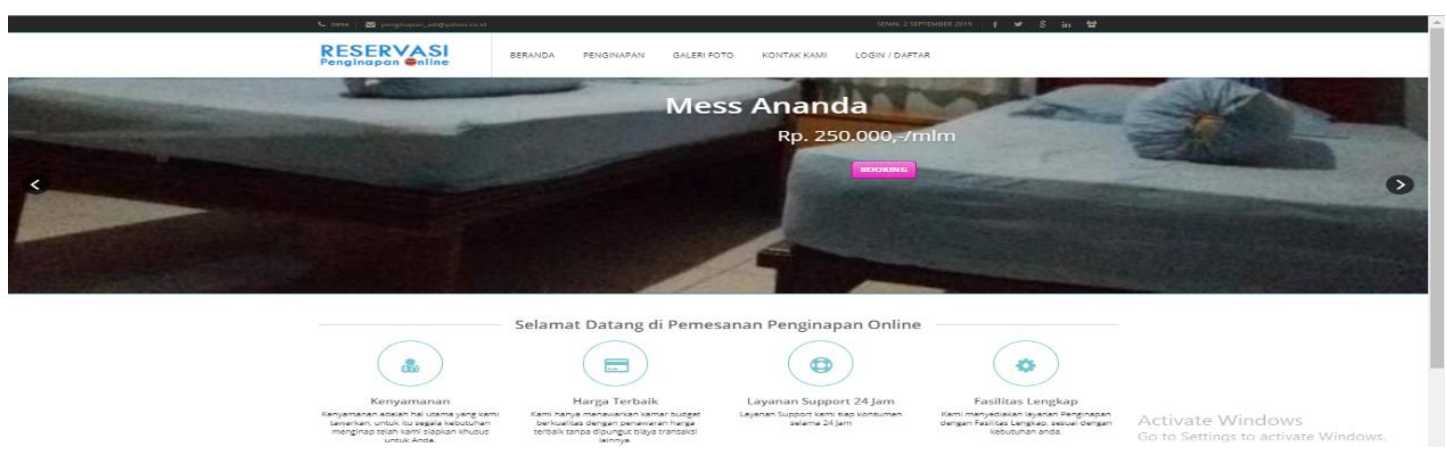

Gambar 11. Halaman Manajemen User

\section{Halaman Penginapan}

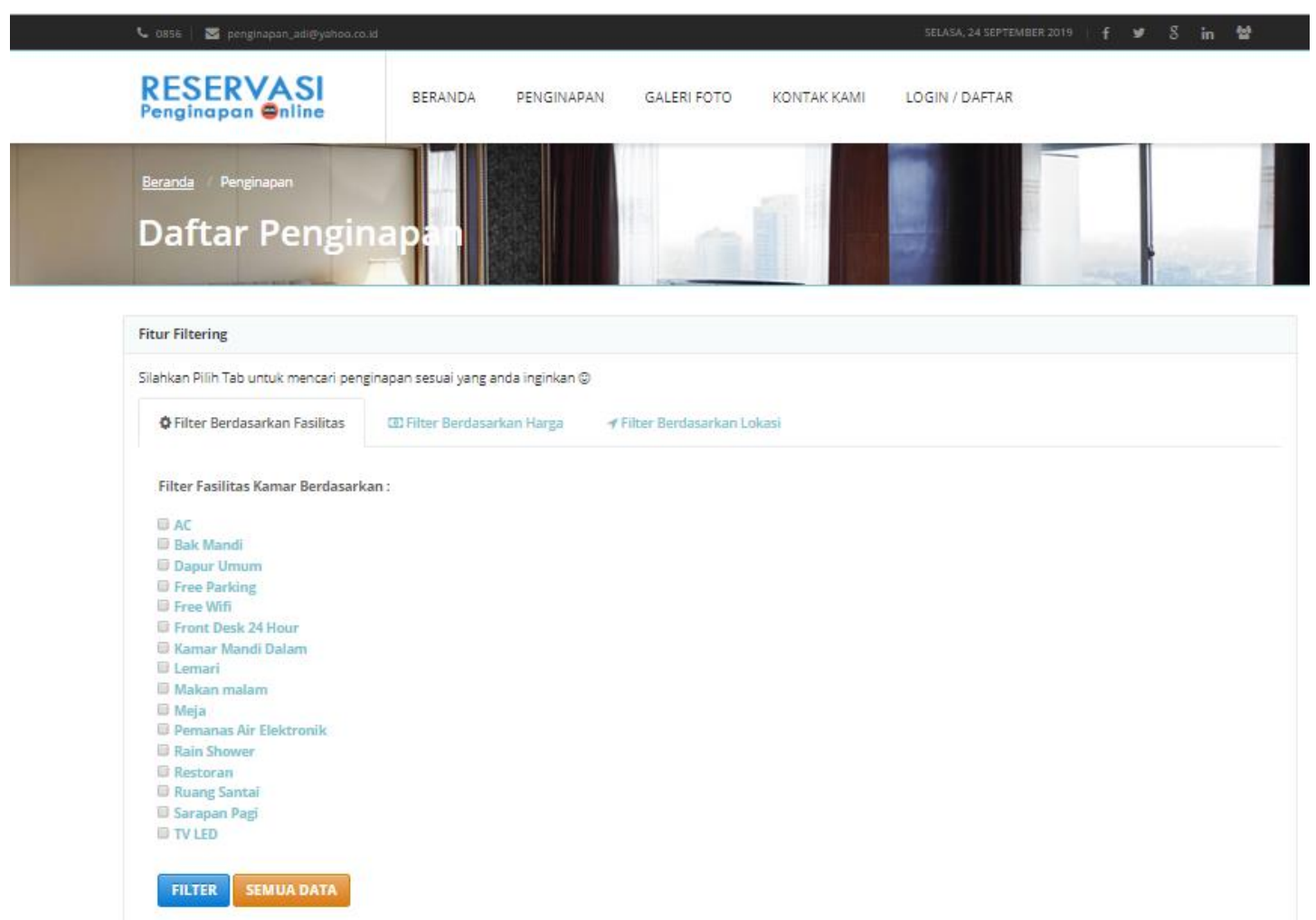

Gambar 12. Halaman Penginapan 


\section{Kesimpulan}

Dalam merancang dan membangun website pemesanan penginapan, degan menggunakan bahasa pemrogramam PHP, dan MySQL sebagai database. Metode pengembangan perangkat lunak yang digunakan yaitu metodologi waterfall yang tahapannya yaitu analisis, desain, koding dan pengujian. Pada tahap analisis, terdapat analisis sistem lama dan sistem baru dan flowchart,lalu menggunakan metodologi DFD setelah itu desain. Pada tahap pengujian(testing) menggunakan metode Black box testing, dimana merupakan strategi testing yang hanya memfokuskan/memperhatikan kepada faktor fungsionalitas dan spesifikasi perangkat lunak.

Jadi pada website ini terpadat 4 aktor yaitu admin sebagai pengelola website, pihak penginapan sebagai orang yang bertugas untuk mengurus penginapan/mengelola penginapan dimana ada penginapan, kamar, fasilitas kamar dan menerima informasi pesanan kamar, lalu berikutnya ada pengunjung yaitu aktor yang mendapatkan informasi dari website ini, tetapi jika pengunjung ingin melakukan pemesanan pengunjung harus mendaftarkan diri menjadi pelanggan terlebih dahulu ada pada fitur Daftar/Login. Setelah pelanggan berhasil mendaftarkan diri pelanggan dapat masuk ke dalam fitur Penginapan lalu pelanggan dapat memilih penginapan dengan filter berdasarkan fasilitas, berdasarkan harga, dan berdasarkan nama jalan/lokasi, setelah itu pelanggan dapat melihat informasi kamar, ketersediaan kamar dan harga kamar. Apabila telah dapat penginapan/kamar yang diinginkan terdapat button booking dengan memilih tanggal checkin dan check-out kamar lalu memilih jumlah kamar yang di pesan, setelah itu lanjut pada konfirmasi pembayaran dengan membayarkan sejumlah uang ke rekening yang ada diwebsite lalu mengisi form konfirmasi pembayaran dan memasukan foto bukti pembayaran. Setelah itu pihak penginapan atau admin dapat memproses konfirmasi pembayaran dan pelanggan tinggal datang ke harinya telah di tentukan.

\section{Daftar Pustaka}

[1] Abdul Kadir, Membuat Aplikasi Web dengan PHP + Database MySQL, 2009 Penerbit Andi Offset Yogyakarta

[2] Alfaris HBI,"Implementasi Black Box Testing Pada Sistem Informasi Pendaftaran Santri Berbasis Web Dengan Menggunakan Php Dan Mysq", 2013, Jurnal Sains dan Teknologi Universitas KH. A. Wahab Hasbullah (UNWAHA)

[3] Jogiyanto," Analisis dan Desain Sistem Informasi”, 2010, Penerbit Andi Offset Yogyakarta

[4] Puspita Ade,"Pengertian DFD", 2013, https://adepuspita28.wordpress.com/2013/10/26/pengertiandata-flow-diagram-dfd-dan-contoh-gambar-dfd/

[5] Sagitajoz, "Pengertian CSS dan Javascript",2013, https://sagitajoz.wordpress.com/2013/10/07/pengertian-css-dan-javascript/

[6] Kanal Wisata, "Jenis-jenis Penginapan (Akomoasi)”,2017, https://kanalwisata.com/jenis-jenispenginapan-akomodasi 